\title{
Multi-dimensional rapid appraisal technique for evaluating the sustainability of energy plantation forests in East Lombok District, Indonesia
}

\author{
BUDI HADI NARENDRA ${ }^{1, \vartheta}$, WIDIATMAKA ${ }^{2}$, CECEP KUSMANA ${ }^{3}$, LINA KARLINASARI ${ }^{4, \bullet \bullet}$, MACHFUD $^{5}$ \\ ${ }^{1}$ Program of Natural Resources and Environmental Management, Institut Pertanian Bogor. Jl. Raya Pajajaran, Kampus IPB Baranangsiang, Bogor \\ 16144, West Java, Indonesia. Tel./fax.: +62-251-8332779, `email: narendra17511@ gmail.com \\ ${ }^{2}$ Department of Soil Science and Land Resources, Institut Pertanian Bogor. Jl. Raya Dramaga, Kampus IPB Darmaga, Bogor 16680, West Java, \\ Indonesia \\ ${ }^{3}$ Department of Silviculture, Faculty of Forestry, Institut Pertanian Bogor. Jl. Raya Dramaga, Kampus IPB Dramaga, Bogor 16680, West Java, Indonesia \\ ${ }^{4}$ Department of Forest Products, Faculty of Forestry, Institut Pertanian Bogor. Jl. Raya Dramaga, Kampus IPB Dramaga, Bogor 16680, West Java, \\ Indonesia. Tel.: +62-251-8621677, Fax.: +62-251-8621256, ^^email: karlinasari@apps.ipb.ac.id \\ ${ }^{5}$ Department of Agro-Industrial Technology, Faculty of Agricultural Technology, Institut Pertanian Bogor. Jl. Kamfer, Kampus IPB Dramaga, Bogor \\ 16680, West Java, Indonesia
}

Manuscript received: 11 February 2019. Revision accepted: 18 March 2019.

\begin{abstract}
Narendra BH, Widiatmaka, Kusmana C, Karlinasari L, Machfud. 2019. Multi-dimensional rapid appraisal technique for evaluating the sustainability of energy plantation forests in East Lombok District, Indonesia. Biodiversitas 20: 1027-1033. The increased use of woody biomass as a renewable energy source should be supported by development of sustainable energy plantation forest. This study aims to evaluate the sustainability status of energy plantation forest in East Lombok District and to determine the leverage attributes affecting sustainability. The evaluation was carried out using rapid appraisal approach, consisting of multidimensional scaling (MDS) analysis to provide sustainability indices for ecological, economic and social dimensions, followed by Monte Carlo simulation to define the validity. Dominant attributes affecting the sustainability were assessed by sensitivity analysis. All analyses were executed using the $R$ software. The evaluation of eight locations generally results in a quite sustainable status for ecological, social, and economic dimensions with the validity index values of $72.73 \%, 61.07 \%$, and $58.49 \%$, respectively. To maintain or enhance sustainability, some leverage attributes need to be prioritized for policy intervention. In the ecological dimension, increasing species diversity using some potential energy woody species should be prioritized. In the social dimension, optimizing the role and capability of forest farmer groups and their members is needed, while for the economic dimension, government should support the expanding area of energy plantation forest managed by each farmer.
\end{abstract}

Keywords: Energy plantation forest, leverage attributes, multi-dimensional scaling, sustainability status

\section{INTRODUCTION}

In Indonesia, energy demand is dominantly fulfilled by fossil fuels which contribute directly to climate change. Thus, increasing the proportion use of renewable energy is quite essential (Nishiguchi and Tabata 2016). However, based on current conditions, efforts and breakthroughs are still needed to promote and expand the use of renewable energy (Sugiyono et al. 2016). As an archipelago supported with abundant natural resources and tropical climate, Indonesia is a country that has enormous and various choices of renewable energy sources. Woody biomass has been traditionally considered as a renewable energy source with relatively low investment and risk (Lee et al. 2015). The development of energy sources from wood potentially becomes a driver of renewable energy because biomass can be developed almost anywhere, is environment-friendly, mitigates global warming, and creates more jobs (Vezmar et al. 2014, Suzuki et al. 2017). Development of plantation forest as wood-based energy source (known as energy plantation forest) has promising prospect compared to food-sourced bioenergy because it will reduce the competition in using productive lands as food production sources. The development of energy plantation forest also potentially reduces deforestation and biodiversity degradation of natural forest (Mehmood et al. 2017).

Community in East Lombok District utilizes more energy wood as an energy source compared to other regencies in West Nusa Tenggara Province. This is used for household consumption and small-scale industries with the largest proportion is used in tobacco processing industries (Bae et al. 2014). The use of energy wood that does not originate from sustainably managed forests is often associated with environmental damage. In order to realize the potential benefits of energy wood, the production must be done in sustainable ways (Jaung et al. 2018). In East Lombok, the practice of forest cultivation for the supply of energy wood has been carried out at a small scale by community and at a larger scale by private company. Currently, the utilization is still limited for firewood, but it has the potential to be developed as a substitute fuel for power plants to replace fossil fuels.

Development of energy wood supply from large-scale tree planting, which is in line with government's programs 
to meet renewable energy source, also provides environmental services like carbon sequestration, and improves degraded land quality (KLHK 2015). A study of potential utilization of degraded lands in East Java and West Java indicates that those degraded lands can be developed as energy plantation forest and the woody biomass product can supply electric power generation to overcome 4.2 million households without electricity (Siregar et al. 2017). Nonetheless, to ensure renewable energy sources to be sustainable, energy wood should be produced from degraded lands without sacrifice productive agricultural lands, carbon stocks, biodiversity, and native vegetation (Jaung et al. 2018). According to the concept of sustainable development, land resources management, including utilization of energy plantation forests, requires integrated management that can guarantee ecological, economic and social sustainability (Phoochinda 2015).

To evaluate the sustainability of energy plantation forests, an analysis is needed to capture the actual general conditions (snapshots) of the three sustainability dimensions. Therefore, this study aims to evaluate the sustainability status of energy plantation forests in East Lombok District based on ecological, economic, and social dimensions as well as to determine the sensitive (leverage) attributes affecting sustainability. The result of the analysis describes a comprehensive sustainability status of energy plantation forests and is very useful for the development planning of similar land management in other locations.

\section{MATERIALS AND METHODS}

\section{Study area}

This research was conducted in East Lombok District, West Nusa Tenggara Province, Indonesia from April 2018 to September 2018. The area lies between $116.361^{\circ}$ $116.761^{\circ} \mathrm{E}$ longitude and $8.935^{\circ}-8.235^{\circ} \mathrm{S}$ latitude. East Lombok has a total land area of 160,000 hectares, dominated by agricultural (44\%) and forested (25\%) lands. Based on the preliminary study through interpretation of high-resolution satellite imageries followed by field survey, there are eight (8) locations of energy plantation forest in East Lombok assessed as units of analysis in the sustainability evaluation (Figure 1).

Energy tree species in those energy plantation forests are dominated by lamtoro (Leucaena leucocephala). Other species are Calliandra calotypes (kaliandra), Gliricidia sepium (gamal), Albizia falcataria (sengon), Sesbania grandiflora (turi), Acacia auriculiformis (akasia), and Eucalyptus camaldulensis (ekaliptus). Lamtoro is the main species producing energy wood from community-owned forest. The forest farmers usually maintain energy wood trees in a high planting density from 10,000 up to 20,000 plants ha ${ }^{-1}$. Lamtoro, kaliandra, and gamal are categorized as short rotation woody crops that have good ability in coppicing after harvesting. The first harvesting can be done in two years after planting and will be followed by the growth of sprouts from each stump. The community uses the energy wood in small amount to fulfill daily needs. A larger quantity is usually sold to local or other district buyers as wood fuel for small industries producing brick, tiled roof, and dried tobacco leaves.

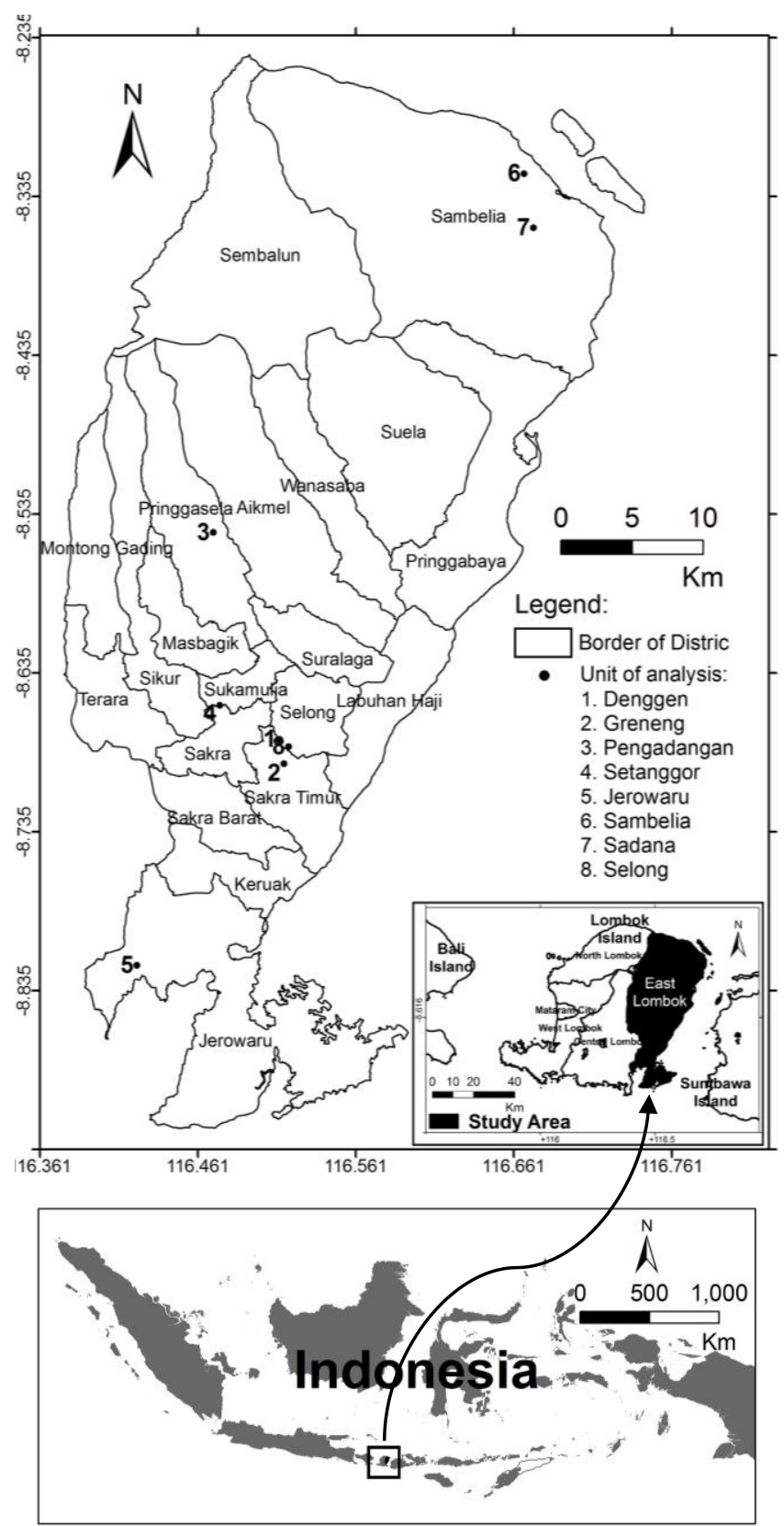

Figure 1. Study area and unit of analysis in East Lombok District, West Nusa Tenggara Province, Indonesia

\section{Sustainability assessment}

The sustainability of each energy plantation forest was assessed using the modified Rapfish technique named Rapsef (Rapid appraisal for sustainable energy forest). The technique simultaneously evaluates the sustainability status of energy plantation forest by considering ecological, social, and economic dimensions. In each dimension, there were attributes determined based on literature review and scientific judgment of related experts. The determined attributes should relate tightly and reflect sustainability to their dimension, not overlapping, be easily and objectively 
scored, and be available of the data required as basis for scoring (Cisse et al. 2014). Based on those criteria, a total of 23 attributes corresponding to three dimensions (Table 1) were scored using questionnaire as guidance.

In the questionnaire, attributes were scored using a standardized, simple semi-quantitative scale run from 0 (worst) to 10 (best) according to information from primary or secondary data (Pitcher et al. 2013). In this research, primary data sources were collected from field observation and in-depth interviews with forestry service officers, experts from universities and forest research institutes, assessor of forest certification institute, forest entrepreneur, and association of forestry farmer. Secondary data in the form of maps and tabular data were obtained from government institutions and libraries. Obtained scoring was then combined and inputted into comma separated values (CSV) format files for Rapsef analysis.

\section{Data analysis}

Sustainability status of energy plantation forest was analyzed using a multidimensional rapid appraisal technique called Rapsef. This technique was derived from improved Rapfish (Rapid Appraisal Technique for Fisheries) and is now available in the $R$ programming language replacing SPSS package and Visual Basic for Excel versions (Pitcher et al. 2013). Rapsef uses a statistical ordination called multidimensional scaling (MDS), Monte Carlo analysis and sensitivity analysis (Adiga et al. 2016). The analysis was performed using the Rapfish algorithm/formula written in $\mathrm{R}$ code and can be downloaded from the Rapfish official website (http: //www.rapfish.org/) (Pitcher et al. 2013). All analysis were run in $R$ software version 3.5.1 (downloaded free form https: //www.r-project.org/) to define sustainability status index of each unit of analysis in each dimension, Monte Carlo simulation, and sensitivity analysis.

MDS is a multivariate statistical analysis that visualizes the position between pairs of objects based on their dissimilarities as distances between points in a twodimensional space (Cisse et al. 2014). The ordination reduces the $\mathrm{F} \times \mathrm{A}$ matrix of forest units $(\mathrm{F})$ and attributes (A) to generate $\mathrm{F} \times 2$-dimensional space that indicates sustainability status index of each forest unit with a scale of 0\% (bad) to-100\% (good) (Cisse et al. 2014). Sustainability index is expressed from score of $0 \%$ (lowest sustainability) to $100 \%$ (best sustainability) and for more detailed uses, it was grouped into four equal category ranges, namely, 0$25.0 \%$ (poor sustainable), 25.1-50.0\% (less sustainable), $50.1-75.0 \%$ (quite sustainable), and $75.1-100 \%$ (very sustainable) (Susilo 2005; Kholil and Puspadewi 2014; Widiatmaka et al. 2015). The comparison of sustainability among the dimension for each unit of analysis can be visualized through a kite diagram.

Monte Carlo, a statistical simulation method, was carried out to express the effect of random error (uncertainty) by assuming a certain statistical value from a normal distribution with a $95 \%$ confidence interval (Cisse et al. 2014). The required iterations numbers are 25 (default) up to 100 (recommended). These random error sources can be the error in scoring due to various knowledge or misunderstanding of respondents, lack of information, data entry error, the stability of iteration, or high-stress value (Fauzi and Anna 2005). Validation of sustainability index of each dimension was calculated through the difference value between sustainability index from the MDS analysis and result of the Monte Carlo simulation (at the confidence interval of 95\%). Sustainability index is valid and considered to be accepted if the difference is no more than 5\% (Papilo et al. 2018).

A sensitivity analysis of individual attributes was conducted to determine leverage attributes that mainly contribute to sustainability index of energy plantation forest. This was performed by removing each attribute sequentially from the MDS analysis. Influence of each attribute can be seen from the change in root mean square (RMS) of ordination. The higher value of the RMS changes due to the removal of a particular attribute means the higher the role of the attribute in establishing the sustainability index (Cisse et al. 2014).

\section{RESULTS AND DISCUSSION}

\section{Sustainability status}

Results of the MDS ordinations indicating the performance of sustainability status for energy plantation forest are shown in Figure 2.

Table 1. Attributes for each dimension of energy plantation forest sustainability assessment

\begin{tabular}{llll}
\hline \multicolumn{1}{c}{ Ecological } & & \multicolumn{1}{c}{ Social } & \multicolumn{1}{c}{ Economic } \\
\hline 1. Vegetation cover & 1. Status of land ownership & 1. Management of harvest period \\
2. Diversity of tree species & 2. Land boundary condition & 2. Contributions to income \\
3. Composition and structure of the stand & 3. Education level of manager & 3. Number of capital sources \\
4. Water availability & 4. Extension or training activities & 4. Managed forest area \\
5. Soil conservation action & 5. Job creation & 5. Government assistance \\
6. Road conditions & 6. Existence of forest farmer groups & 6. Marketing scheme \\
7. Suitability to the spatial planning & 7. Population pressure to the land & 7. Fluctuations in product prices \\
8. Use of chemical fertilizer or insecticide & 8. Land conflict & \\
\hline
\end{tabular}



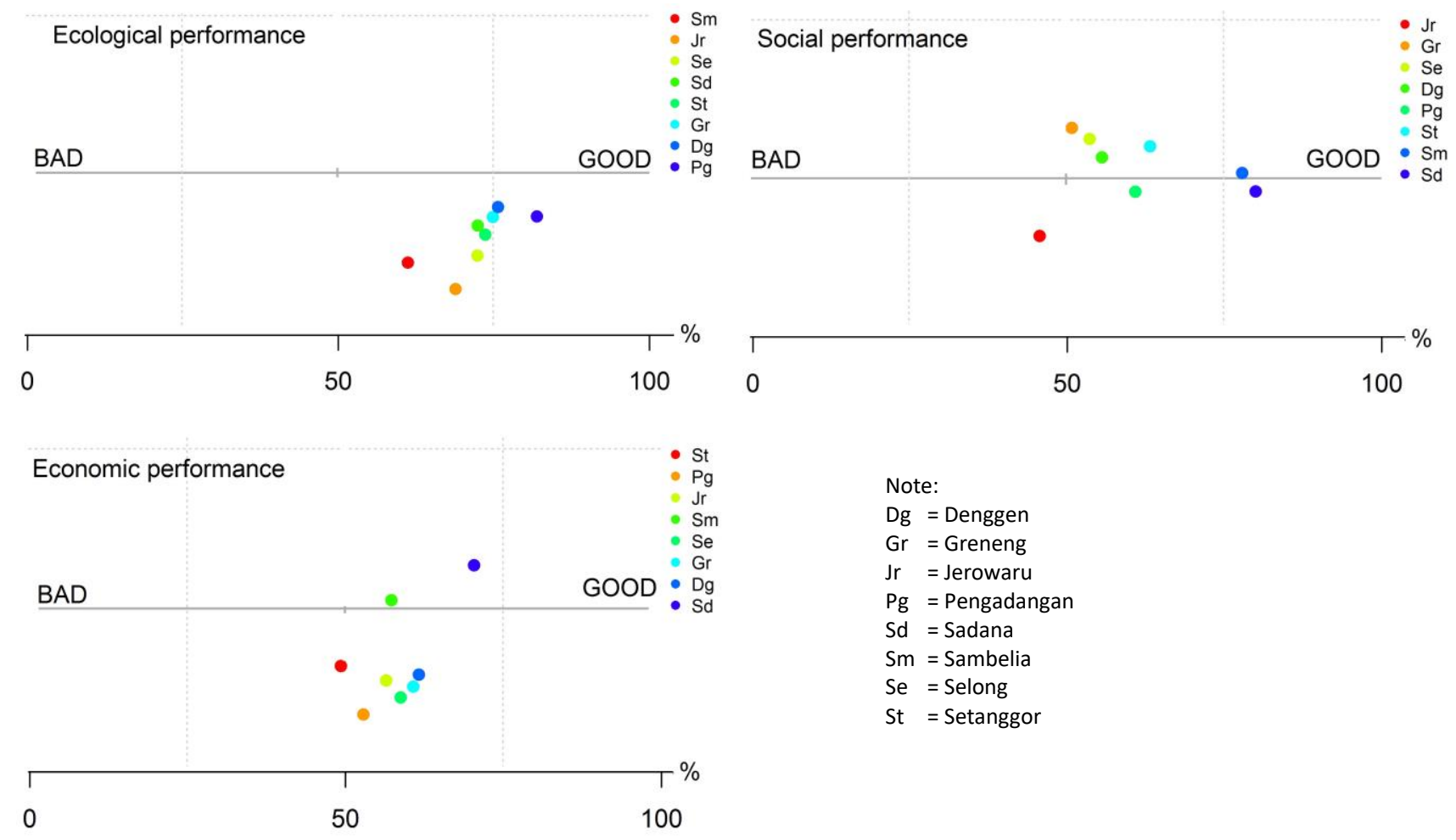

Figure 2. Ordination plots for each sustainability dimension resulted from the MDS analysis

Each energy plantation forest represented by colored points are spread out along a horizontal scale line according to their relative sustainability in each ecological, social, and economic dimension. The vertical position of the points expresses differences not related to sustainability. Although two points have the same sustainability performance showed by the horizontal positions, the difference in vertical position was caused by different combinations of attribute scores achieved by each point (Pitcher and Preikshot 2001; Cisse et al. 2014; Adiga et al. 2016). For example, in the economic performance showed by Figure 2, Jerowaru (Jr) and Sambelia ( $\mathrm{Sm})$ points have almost the same indices (56.52 and 57.33). Their vertical positions are separated quite far because Jerowaru location has higher scores for capital sources and government assistance attributes, while the Sambelia's scores were higher in income contribution and forest area attributes.

In the ordination plot of ecological dimension, all of energy plantation forests are located in more than $50 \%$ values, indicating that those forests are quite sustainable up to very sustainable. In social and economic dimensions, most of the points are located around $50 \%$ values, and some of them are lower than $50 \%$. It indicates that in social and economic aspect, some energy plantation forests have less sustainable status. Table 2 contains detail on sustainability indices per location for each dimension, and overall sustainability performance is shown in mean column.

These results indicate that all units of analysis generally have a quite sustainability index based on overall sustainability. Among the three dimensions, the ecological dimension has a relatively higher sustainability value with $61 \%$ as the lowest value and $82 \%$ as the highest, while the social and economic dimensions have relatively balanced values with the lowest values for all assessments in the social dimension found at the energy plantation forest in Jerowaru. Coupled with the lowest index in the ecological dimension, Jerowaru has the lowest rank in sustainability. A kite diagram resulted from the combination of all MDS analysis fields is shown in Figure 3.

From all dimension, the ecological dimension has the highest total score and is categorized as quite sustainable. The social and economic dimensions, although with lower total scores, have the values included in the range of quite sustainable (50.1-75.0\%).

Table 2. Sustainability indices of each location according to MDS ordination

\begin{tabular}{|c|c|c|c|c|c|}
\hline \multirow{2}{*}{$\begin{array}{c}\text { Location of } \\
\text { the analysis } \\
\text { unit }\end{array}$} & \multicolumn{3}{|c|}{ Sustainability index $(\%)$} & \multirow[b]{2}{*}{ Mean } & \multirow[b]{2}{*}{ Rank } \\
\hline & Ecological & Social & Economic & & \\
\hline Sadana & 72.55 & 80.13 & 70.43 & 74.37 & 1 \\
\hline Pengadangan & 82.06 & 61.00 & 52.91 & 65.32 & 2 \\
\hline Sambelia & 61.33 & 78.01 & 57.33 & 65.56 & 3 \\
\hline Denggen & 75.80 & 55.67 & 61.72 & 64.40 & 4 \\
\hline Greneng & 74.95 & 50.91 & 60.82 & 62.23 & 5 \\
\hline Setanggor & 73.73 & 63.34 & 49.33 & 62.13 & 6 \\
\hline Selong & 72.47 & 53.74 & 58.83 & 61.68 & 7 \\
\hline Jerowaru & 68.94 & 45.78 & 56.52 & 57.08 & 8 \\
\hline
\end{tabular}




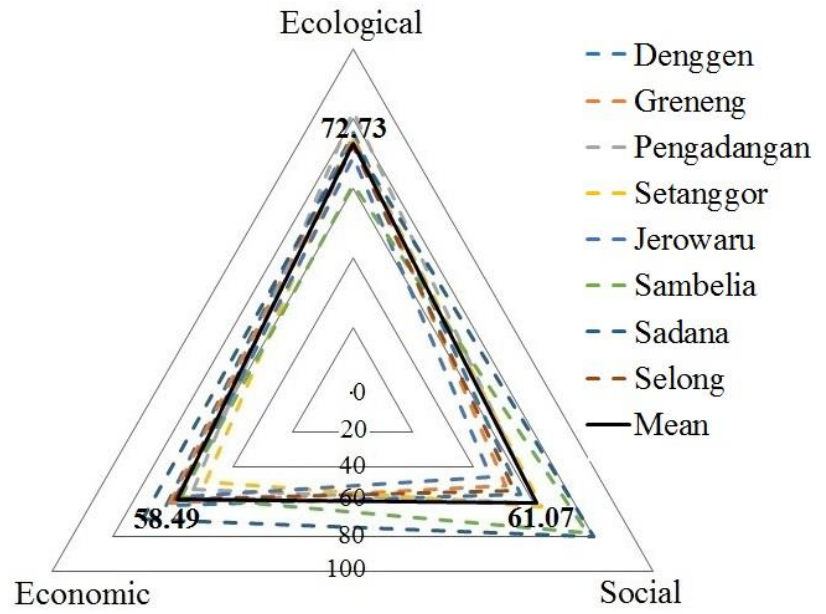

Figure 3. Kite diagram representing sustainability indices of energy plantation forest in the three dimensions

\section{The validity of sustainability indices}

To investigate the uncertainty in Rapsef analysis, Monte Carlo simulation has been carried out through 100 iterations. The validation of sustainability indices of each dimension was assessed by calculating the difference value between sustainability index from the MDS analysis and
Monte Carlo simulation result at a confidence interval of 95\%. The validation result in Table 3 assures the robustness of the Rapsef results.

The result shows that the difference between the average value of the two analyses, MDS and Monte Carlo, is very small $(<5 \%)$ in all the dimensions. This uncertainty analysis suggests that the sustainability index resulted from Rapsef has been quite good, considered to be accepted, and does not require to be repaired because the difference is not more than 5\% in each dimension (Adiga et al. 2016; Papilo et al. 2018).

\section{Leverage attributes}

Sensitivity analysis was carried out to determine leveraging attributes that play more dominant roles in determining the sustainability index for each dimension. The sensitivity level of each attribute based on the root mean square (RMS) change is illustrated in Figure 4.

Table 3. Validation of sustainability index

\begin{tabular}{lccc}
\hline Dimension & MDS index (\%) & $\begin{array}{c}\text { Monte Carlo } \\
\text { result }(\boldsymbol{\%})\end{array}$ & Difference (\%) \\
\hline Ecological & 72.73 & 72.57 & 0.16 \\
Social & 61.07 & 60.89 & 0.19 \\
Economic & 58.49 & 58.51 & 0.03 \\
\hline
\end{tabular}

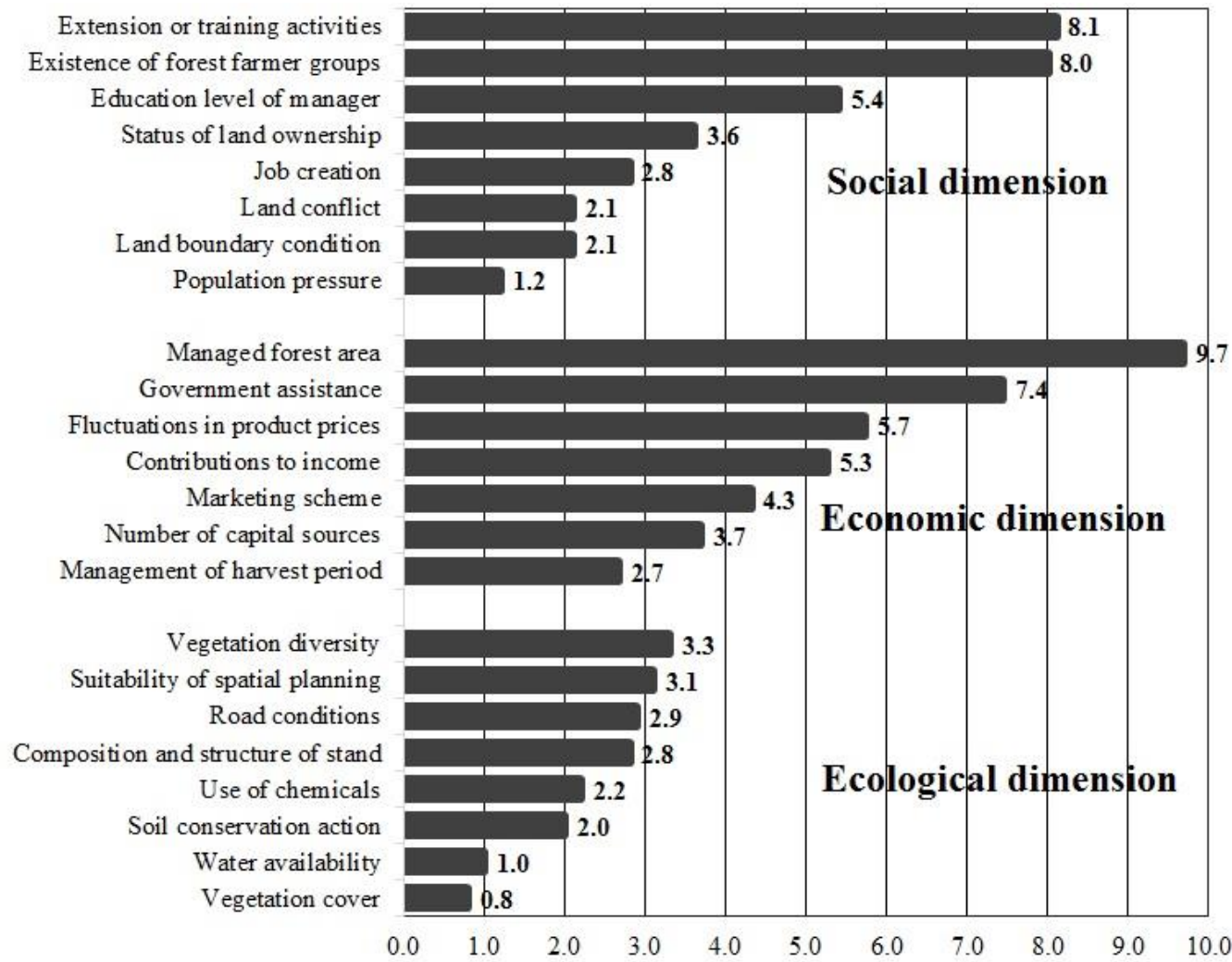

Figure 4. Root mean square changes (\%) indicate prioritizing of sustainability attributes 
Figure 4 illustrates the leverage of each individual attribute. In the context of management and policy interventions, leverage attributes with high RMS value need to be prioritized to maintain or improve the sustainability status. In the ecological dimension, leverage attribute with the highest value is the diversity of vegetation in the energy plantation forest. The social and economic dimensions show greater RMS heterogeneity than the ecological dimension. In social dimension, extension or training activities, as well as the existence of forest farmer groups, becomes the highest leverages influencing social sustainability. Regarding the economic dimension, the highest sensitivity levels are extending the area of managed forest and government assistance.

Further calculation for overall sustainability indices in the kite diagram will produce an average value of $64.10 \%$ for all three sustainability values. This value indicates that the existence of energy plantation forest in East Lombok has quite sustainable status. The sustainability index in ecological dimension is greater than in social and economic dimensions. In this dimension, differences in sustainability indices among locations are relatively small. The highest score is $82.06 \%$ by forest in Pengadangan, and the lowest is $61.33 \%$ by forest in Sambelia. The high score in Pengadangan is supported by a high diversity of tree species. In this location, we found eight tree species planted in one location although not all of them were planted as energy wood sources. The species planted for energy wood are Calliandra calothyrsus (kaliandra), Gliricidia sepium (gamal), and Leucaena leucocephala (lamtoro). Other species found in the location are Swietenia macrophylla (mahagoni), Aleurites moluccana (kemiri), Albizia falcataria (sengon), Tectona grandis (jati), and Gmelina arborea (gmelina). These species dominate the forest area, but the products are mainly used as woodworking and sawn timber. Therefore, contribution of these timber-producing species to family income is higher than those from energy-generating species. Sambelia location indicates the lowest ecological score due to it has low scores for several assessment attributes especially for species diversity, composition, and structure of the stand, and soil conservation application.

The social dimension has the widest value range of sustainability index with a maximum score of $80.13 \%$ in Sadana location, while the lowest is $45.78 \%$ for the forest in Jerowaru. The low attribute's scores in Jerowaru is mainly caused by there is almost no activity of extension or training to develop farmer's knowledge in forest plantation fields, and they also do not have a community group especially for the owners or farmers managing energy plantation forest. The lowest value in the social dimension is also affected by the low educational level of forestry farmers. On the other hand, the forest in Sadana shows the highest social score because it has relatively high scores for all social attributes. Sadana has the biggest area of energy plantation forest in East Lombok, and they manage the forest professionally as a private company. Although Sadana sometimes faces land conflict with certain communities around its area, they also build a partnership with some cooperative village communities to manage a small part area. Therefore, Sadana is also superior in economic dimension through strict product arrangements, definite marketing of the product, and adequate financial support and management even though they do not receive assistance from the government.

The opposite condition with Sadana's economic sustainability is the forest in Setanggor with the lowest score in the economic dimension. This is due to the limited area of managed forest, contributing to low income of farmers and also due to the absence of facilities and infrastructure support from the government.

To maintain or increase the sustainability status, leverage attributes indicated in Figure 4 are needed to be considered and prioritized in policy interventions. In ecological dimension, although the attributes have low sensitivity values to develop the ecological sustainability, firstly farmers should consider increasing species diversity using potential energy tree species such as Calliandra calothyrsus, Gliricidia sepium, Leucaena leucocephala, and Sesbania grandiflora. The stand structure will achieve better sustainability by conducting harvest rotation. A plantation forest with higher diversity in genotype, species, and structure will decrease the vulnerability to abiotic and biotic disturbances (Verheyen et al. 2016).

To increase sustainability in social dimension, the government should intensify forestry extension activities and provide training to forest farmers in managing energy plantation forests. Extension and training activities are important for forest farmer to enhance their knowledge, capacity, and skills in technical practices of sustainable forest management (Sukwika et al. 2016). Another effort to improve sustainability in social dimension is by increasing the role of forest farmer groups. The groups are commonly established to provide a forum for people whose lives also depend on the income from forest management. To enhance sustainability in social dimension, the existence of this kind of group must be optimized to be able to accommodate members' aspirations, communicate the positive knowledge among the members, and build a partnership with the private company, government, and NGOs (Wahyudiyati and Irawanti 2015).

Efforts in optimizing farmer groups will also potentially increase economic sustainability because if a farmer group can run well, it gradually supports economic level of its members. Based on sensitivity analysis, the most important attribute to enhance economic sustainability is by extending forest area managed by forest farmers. Commonly, forest farmers in East Lombok manage energy plantation forest in a small land area. On the other hand, there are still opportunities for people to manage state forest areas in East Lombok District as energy plantation forest, especially in degraded production forest areas. The government through the Ministry of Environment and Forestry launched a program that offers legal access for community to manage state forest area through Ministerial Decree Number 83 in the year 2016 about social forestry. Social forestry has three main goals, namely distributing forest use rights to local communities, improving livelihood development, and achieving forest conservation (Fisher et al. 2018). In practice, several schemes can be 
implemented that allow forest farmers to manage state forest area, including village forest (HD), community forest $(\mathrm{HKm})$, and people plantation forest (HTR). The preliminary evaluation of the scheme implementations showed that the community still require technical support, financial assistance, and forest managerial skills to run the schemes efficiently (Royer et al. 2018).

In conclusion, evaluation of sustainability of energy plantation forest in East Lombok District generally results in a quite sustainable status with $64.10 \%$ for the overall index. In ecological, social, and economic dimensions, the assessment showed $72.73 \%, 61.07 \%$, and $58.49 \%$ index values respectively. Some leverage attributes that need to get more attention to improve the sustainability status are species diversity (in the ecological dimension), the capability of forest farmers and forest farmer groups (social dimension), and area of forest managed by farmers (economic dimension).

\section{ACKNOWLEDGEMENTS}

The authors would like to acknowledge the Directorate General for Strengthening Research and Development, Ministry of Research, Technology, and Higher Education for the funding of this research. We gratefully acknowledge the support from USAID through the SHERA program Centre for Development of Sustainable Region (CDSR). In year 2017-2021 CDSR is led by Center for Energy Studies, Gadjah Mada University (UGM), Yogyakarta, Indonesia.

\section{REFERENCES}

Adiga MS, Ananthan PS, Kumari HVD, Ramasubramanian V. 2016 Multidimensional analysis of marine fishery resources of Maharashtra, India. Ocean Coast Manag 130: 13-20.

Bae JS, Kim C, Kim YS, Latifah S, Afifi M, Fisher LA, Lee SM, Kim IA, Kang J, Kim R, Kim JS. 2014 Opportunities for Implementing REDD+ to Enhance Sustainable Forest Management and Improve Livelihoods in Lombok, NTB, Indonesia. Working Paper. CIFOR, Bogor. [Indonesian]

Cisse AA, Blanchard F, Guyader O. 2014. Sustainability of tropical smallscale fisheries: Integrated assessment in French Guiana. Mar Policy 44: 397-405.

Fauzi A, Anna S. 2005. Pemodelan Sumberdaya Perikanan dan Kelautan untuk Analisis Kebijakan. Gramedia Pustaka Utama, Jakarta. [Indonesian]

Fisher MR, Moeliono M, Mulyana A, Yuliani EL, Adriadi A, Kamaluddin, Judda J, Sahide MAK. 2018. Assessing the New Social Forestry Project in Indonesia: Recognition, Livelihood and Conservation? Intl Forest Rev 20 (3): 346-361.

Jaung W, Wiraguna E, Okarda B, Artati Y, Goh CS, Syahru R, Leksono B, Prasetyo LB, Lee SM, Baral H. 2018. Spatial assessment of degraded land for biofuel production in Indonesia. Sustainability 10: 1-17.

Kholil, Puspadewi IJ. 2014. The use of MDS (Multidimensional Scaling) method to analyze the level of sustainability of fisheries resources management in Thousand Islands, Indonesia. Intl J Mar Sci 4 (27): 245-252.

KLHK. 2015. Rencana strategis Kementerian Lingkunggan Hidup dan Kehutanan tahun 2015-2019. Kementerian Lingkungan Hidup dan Kehutanan, Jakarta. [Indonesian]

Lee SM, Kim Y, Jaung W, Latifah S, Afifi M, Fisher LA. 2015. Forests, fuelwood and livelihoods-energy transition patterns in eastern Indonesia. Energ Pol 85: 61-70.

Mehmood MA, Ibrahim M, Rashid U, Nawaz M, Ali S, Hussain A, Gull M. 2017. Biomass production for bioenergy using marginal lands. Sust Prod Consum 9: 3-21.

Nishiguchi S, Tabata T. 2016. Assessment of social, economic, and environmental aspects of woody biomass energy utilization: Direct burning and wood pellets. Renew Sust Energ Rev 57: 1280-1286.

Papilo P, Marimin, Hambali E, Sitanggang IS. 2018. Sustainability index assessment of palm oil-based bioenergy in Indonesia. J Clea Prod 196: 808-820.

Phoochinda W. 2015. Sustainability approach for energy production using biomass at household and community levels: A case study in Thailand. Intl J Renew Energy Res 5 (3): 859-872.

Pitcher TJ, Preikshot D. 2001. RAPFISH: a rapid appraisal technique to evaluate the sustainability status of fisheries. Fisheries Research. 49(3):255-270.

Pitcher TJ, Lam ME, Ainsworth C, Martindale A, Nakamura K, Perry RI, Ward T. 2013. Improvements to Rapfish: a rapid evaluation technique for fisheries integrating ecological and human dimensions. J Fish Biol 83 (4): 865-889.

Royer SD, Noordwijk MV, Roshetko JM. 2018. Does community-based forest management in Indonesia devolve social justice or social costs? Intl Forest Rev 20 (2): 167-180.

Siregar UJ, Narendra BH, Suryana J, Siregar CA, Weston C. 2016. Evaluation on community tree plantation as a sustainable source for rural bioenergy in Indonesia. Earth Environ Sci 65 (1): 12-19.

Sugiyono A, Anindhita, Wahid LMA, Adiarso. 2016. Outlook Energi Indonesia 2016: Pengembangan Energi untuk Mendukung Industri Hijau. Pusat Teknologi Sumber Daya Energi dan Industri Kimia (PTSEIK), Badan Pengkajian dan Penerapan Teknologi (BPPT), Jakarta. [Indonesian]

Sukwika T, Darusman D, Kusmana C, Nurrochmat DR. 2016. Evaluating the level of sustainability of privately managed forest in Bogor, Indonesia. Biodiversitas 17 (1): 241-248.

Susilo SB. 2005. Small islands development sustainability: a case study in Kelurahan Panggang and Pulau Pari, Kepulauan Seribu, DKI Jakarta. J. Teknologi Perikanan dan Kelautan Maritek 5 (2): 85-110. [Indonesian]

Suzuki K, Tsuji N, Shirai Y, Hassan MA, Osaki M. 2017. Evaluation of biomass energy potential towards achieving sustainability in biomass energy utilization in Sabah, Malaysia. Biomass Bioenerg 97: 149-154.

Verheyen K, Vanhellemont M, Auge H, et al. 2016. Contribution of global network of tree diversity experiments to sustainable forest plantation. Ambio 45: 29-41.

Vezmar S, Spajik A, Topic D, Sljivac D, Lajor J. 2014. Positive and negative impacts of renewable energy sources. Int J Elect Comput Eng Sys 5 (2): 15-23.

Wahyudiyati KT, Irawanti S. 2015. Forest farmer groups in Indonesia. Eur Trop For Network 57: 126-132.

Widiatmaka, Munibah K, Sitorus SRP, Ambarwulan W, Firmansyah I. 2015. Appraisal keberlanjutan multidimensi penggunaan lahan untuk sawah di Karawang, Jawa Barat. Kawistara 5 (2): 113-131. [Indonesian] 